\title{
LANDLORD MORTGAGE DEFAULTS AND STATUTORY TENANT PROTECTIONS IN U.S. FORECLOSURE AND U.K. REPOSSESSION ACTIONS: A COMPARATIVE ANALYSIS
}

\author{
Ryan K. Lighty*
}

The ache for home lives in all of us,

the safe place where we can go as we are and not be questioned.

-Maya Angelou

\section{INTRODUCTION}

During the 2007-2009 global financial crisis, ' mortgage foreclosure rates in the United States rose to levels not seen since the Great Depression. $^{2}$ Repossession rates in the United Kingdom also spiked, demonstrating that this phenomenon was not limited to the American side of "the pond." While many media reports acknowledge the ills of owneroccupants mired in the modern foreclosure crisis, renters are often the forgotten victims. ${ }^{4}$

The foreclosure/repossession problem has affected not-quite-innocent parties such as banks that gave bad loans and homeowners who took loans they could not afford. ${ }^{s}$ However, the effects also reach a large percentage of people who are losing their principal place of residence through no fault

* Honor Law Graduate, Office of the General Counsel, U.S. Nuclear Regulatory Commission. $\dagger$ Doctor of Jurisprudence, cum laude, Indiana University School of LawIndianapolis. Bachelor of Science, Political Science-Legal Studies, Indiana State University. The author would like to thank Greg and Marlene Lighty for a lifetime of encouragement and Jason Poorboy for the unwavering support that made this article possible.

† The views and opinions expressed herein are solely those of the author and do not necessarily represent the views and opinions of the U.S. Nuclear Regulatory Commission or the United States Government.

1. See generally William Poole, Causes and Consequences of the Financial Crisis of 2007-2009, 33 HARV. J.L. \& PUB. POL'Y 421, 422-26 (2010) (discussing the causes of and conditions leading to the financial crisis).

2. Lawrence H. White, How Did We Get into This Financial Mess?, CATO INST. (Nov. 18, 2008), http://www.cato.org/pub_display.php?pub id=9788.

3. Mark Smith, In Brief: Home Repossessions 'Set for New Record', ScOTSMAN (Edinburgh, Scotland), Nov. 12, 2009, http://thescotsman.scotsman.com/politics/Homerepossessions--39set-for.5816967.jp.

4. Tim Logan, Renters Often Become the Forgotten Victims, ST. LouIS PosTDispaTCH, June 28, 2008, at B1, available at 2008 WLNR 11664140.

5. Id. 
of their own: renters. ${ }^{6}$ Many of these renters are innocent victims of the battered global economy. ${ }^{?}$

If a borrower defaults on a promissory note and mortgage, the bank may reclaim its possessory interest and sell the property to fulfill the outstanding debt. ${ }^{8}$ This may force an owner, or tenant, to vacate the property. ${ }^{9}$ At common law, renters have few rights, if any, when the property's owner defaults on the promissory note of a mortgaged rental property; renters can be forced to suddenly leave their home. ${ }^{10}$ This is an especially harsh scenario if the tenant has "clean hands" and has made timely rent or lease payments.

The number of people affected by this phenomenon is significant. ${ }^{11}$ Recent estimates suggest that a substantial number of foreclosures involve a landlord-tenant relationship. ${ }^{12}$ In fact, in New York City, nearly $60 \%$ of the 15,000 notices of foreclosure filed in 2007 were on multi-family buildings. ${ }^{13}$ Ejectments-orders directing homeowners to vacate properties sold at an auction or sheriff's sale-have more than doubled in some places. $^{14}$

The harms that flow to renters from landlord defaults are significant. Unscrupulous landlords facing a foreclosure or repossession are not likely to maintain the property and often raid the tenant's security deposit for use on the mortgage payment. ${ }^{15}$ In addition, since a foreclosure or repossession action essentially erases any existing lease agreement, tenants can be evicted from the premises. ${ }^{16}$ This involuntary displacement causes irreparable detriment to both occupants and society in general. ${ }^{17}$

As one scholar notes, "[m]ost . . renters are not wealthy enough to obtain security of tenure by agreement with the landowner, and therefore

6. See Arminé Bazikyan, Comment, Renters: The Innocent Victims of the Foreclosure Mortgage Crisis, 39 Sw. L. REv. 339 (2009).

7. See Creola Johnson, Renters Evicted En Masse: Collateral Damage Arising from the Subprime Foreclosure Crisis, 62 FLA. L. REV. 975, 975 (2010).

8. Caryl A. YzenbaARD, Residential Real Estate Transactions $\$ 4: 37$ (Thomson/West 2005).

9. Id.

10. See Aleatra P. Williams, Symposium, Real Estate Market Meltdown, Foreclosures and Tenants' Rights, 43 IND. L. REV. 1185, 1196-97 (2010).

11. Vicki Been \& Allegra Glashausser, Tenants: Innocent Victims of the Nation's Foreclosure Crisis, 2 ALB. Gov'T L. REv. 1, 4-5 (2009).

12. Bazikyan, supra note 6, at 348-49.

13. Been \& Glashausser, supra note 11.

14. Alan J. Heavens, As Moratoriums Expire, Home Ejections Climb, PHILADElPHIA INQUIRER, June 16, 2009, at C02, available at 2009 WLNR 11487756.

15. Bazikyan, supra note 6 , at $350-51$.

16. Johnson, supra note 7 .

17. See Florence Wagman Roisman, The Right to Remain: Common Law Protections for Security of Tenure: An Essay in Honor of John Otis Calmore, 86 N.C. L. REV. 817 (2008). 
rely upon the government to assure them some protection against ... terminations of occupancy." 18 In response to this reality, there have been many approaches to altering the strict common law outcome. From procedural rules in the United Kingdom that extend the notice period for ejecting tenants, ${ }^{19}$ to local law enforcement directives that obligate purchasers of foreclosed homes to provide relocation costs to ousted tenants, ${ }^{20}$ to United States laws that require institutional purchasers to honor existing lease agreements regardless of priority, ${ }^{21}$ government solutions have been diverse.

Statutory protections for tenants facing foreclosure or repossession are relatively new. ${ }^{22}$ Part I of this Note examines the need for statutory tenant protections and discusses the research and lobbying work of tenant advocacy groups. Specifically, Part I focuses on independent research studies that show substantial numbers of renting individuals and families are affected by landlord foreclosure. Furthermore, these studies highlight the significant individual and societal harms that flow from involuntary displacement of innocent tenants.

Parts II and III examine statutory tenant protections in the United States and the United Kingdom, respectively. The bulk of these discussions focus on two major legislative undertakings: the Protecting Tenants at Foreclosure Act of 2009 (U.S.) and the Mortgage Repossessions (Protection of Tenants etc) Act 2010 (U.K.). This Note scrutinizes the textual meaning and underlying legislative intent of these Acts. Criticisms of these legislative works are also explored, along with the possibilities for future statutory tenant protections. Part IV considers recommendations for improving the Acts and highlights lessons the Americans can learn from the British, and vice-versa. Finally, the Note concludes that statutory tenant protections must become permanent fixtures of United States and United Kingdom law.

\section{PART I: THE NEED FOR STATUTORY TENANT PROTECTIONS}

In order to comprehensively evaluate tenant protection legislation, it is important to first consider the underlying issues giving rise to public demand for such laws. Awareness of the structural deficiencies of the

18. Id. at $817-18$.

19. Chiara Cavaglieri, Tenants Left Homeless by Defaulting Landlords, INDEPENDENT ON SUNDAY (UK), July 5, 2009, http://www.independent.co.uk/money/spend-save/tenantsleft-homeless-by-defaulting-landlords-1731820.html.

20. Tom Clark, Sheriff's Office Details How Eviction Process is Supposed to Work, PhiladelPhIA DaILY NeWS, June 16, 2009, at 6, available at 2009 WLNR 11487794.

21. Protecting Tenants at Foreclosure Act of 2009, Pub. L. No. 111-22, $\S \S 701-704$, 123 Stat. 1632 (2009).

22. See, e.g., id. 
common law will help inform a pertinent analysis regarding the necessity or adequacy of current legislation. This section discusses the importance of security of tenure and examines multiple policy-relevant findings that point to the need for statutory tenant protections.

\section{A. Security of Tenure and Involuntary Displacement}

Throughout history, the concept of "home" has carried special meaning. ${ }^{23}$ It can impart a sense of belonging, comfort, and security. ${ }^{24}$ Research indicates that "homes are sources of feelings of rootedness, continuity, stability, permanence, and connection to larger social networks." 25 A home can also provide individuals with a sense of citizenship, personhood, and identity. ${ }^{26}$ Indeed, people's homes are their castles; "[b]y their physical nature, homes provide their inhabitants with a measure of security against attack or invasion by other individuals" or by the government. ${ }^{27}$ United States Supreme Court Justice Oliver Wendell Holmes even noted, "[h]ousing is a necessary of life.",28

Security of tenure is the right of a tenant to continue to occupy a dwelling or site absent good cause. ${ }^{29}$ It is arguably "one of the most important elements of the human right to housing" because it is "the basis upon which residents build their lives." ${ }^{30}$ This continuity provides a foundation for school attendance, religious exercise, social participation, and employment activities of children and adults. ${ }^{31}$ With so much at stake, it is easy to see why security of tenure provides much more than mere socioeconomic status.

"Involuntary displacement from a home is an obvious, immediate, and tangible injury."32 When tenants are involuntarily displaced, their ability to make financial, psychological, and emotional investments in their

23. Kristen David Adams, Do We Need A Right To Housing?, 9 NEv. L.J. 275, 305 (2009).

24. Id. at 305-07.

25. D. Benjamin Barros, Home as a Legal Concept, 46 SANTA ClaRA L. REV. 255, 277 (2006).

26. Adams, supra note 23, at 307-09. See generally Michael Sorkin, More or Less, in THE HOME House ProJect: THE Future of AfFordable Housing 10 (David J. Brown ed., 2004) (arguing that a home is a means of asserting personal identity); Padraic Kenna, Housing Rights - The New Benchmarks for Housing Policy in Europe?, 37 URB. LAW. 87 (2005) (asserting that housing is an important component of fully realized personhood).

27. Barros, supra note 25 , at 260.

28. Block v. Hirsh, 256 U.S. 135, 156 (1921).

29. Roisman, supra note 17 , at 819 .

30. Id. at 820 .

31. Id.

32. Ann B. Lever \& Todd Espinosa, A Tale of Two Fair Housing Disparate-Impact Cases, 15-SPG J. AFFORDABLE HOUSING \& COMMUNITY DEV. L. 257, 261 (2006). 
homes and neighborhoods is disrupted. ${ }^{33}$ For the elderly, it can cause even greater harms including illness and death. ${ }^{34}$

Residential instability is a major cause of school-related problems for children. ${ }^{35}$ These problems can cause serious educational and social disruptions for both transient students as well as the non-transient students in a classroom. ${ }^{36}$ Involuntary displacement can even lead to literal homelessness for poor individuals who may be unable to make timely alternative living arrangements. ${ }^{37}$ Homelessness has its own set of distinct detrimental effects including "division of families, with children wrested from their parents' custody to be institutionalized or placed into foster care." ${ }^{38}$ When involuntarily displaced tenants suffer physical or mental injury, family disruption, homelessness, or foster care placement because of forced displacement, society bears heavy financial and other costs. ${ }^{39}$ Reduction or elimination of these societal harms should be a key goal of tenant protection legislation.

\section{B. Policy Arguments for Statutory Tenant Protections in the United States}

According to a 2008 report by the National Low Income Housing Coalition (NLIHC), ${ }^{40}$ six distinct and policy-relevant findings point to the need for statutory tenant protections. ${ }^{41}$ These findings highlight the significant number of individuals affected by landlord default scenarios, the harms incurred by these individuals, and the ease with which mitigation can be achieved via simple statutory safeguards.

The first finding notes that, "[m]ore than $20 \%$ of the properties facing foreclosure nationwide are rentals." The NLIHC points out that the Mortgage Bankers Association (MBA) ${ }^{43}$ estimates that one in five

33. Roisman, supra note 17 , at 820 .

34. Id. at 822 .

35. Id. at $821-22$.

36. Id. at 822 .

37. Id. at 823 .

38. Id.

39. Id. at 828 .

40. The NLIHC is an advocacy group "dedicated solely to achieving socially just public policy that assures people with the lowest incomes in the United States have affordable and decent homes." NaTiOnal LOW INCOME Housing CoALiTION, http://www.nlihc.org (last visited May 22, 2011).

41. Danilo Pelletiere, National low Income Housing Coalition, Renters in Foreclosure: Defining the Problem, Identifynng Solutions 4 (2008), available at http://www.nlihc.org/doc/renters-in-foreclosure.pdf.

42. Id. at 6.

43. The MBA "is the national association representing the real estate finance industry ... ." About MBA, MORTGAGE BANKERS Ass'N, http://www.mbaa.org/AboutMBA (last visited May 22, 2011). 
properties with a delinquent mortgage is not owner-occupied. RealtyTrac ${ }^{44}$ speculates that the number is closer to one in three, but climbs to roughly half of all foreclosures in Nevada, Illinois, and New York; and Hennepin County, Minnesota, conducted its own investigation revealing that fortythree percent of the county's foreclosed properties were tenant-occupied. ${ }^{45}$ These findings illustrate the significant number of homes potentially affected by a landlord default situation.

Second, "[b]ecause rental properties often are home to multiple families, renters make up roughly $40 \%$ of the families facing eviction., 46 Studies conducted by the NLIHC, the Furman Center for Real Estate and Urban Policy, $^{47}$ and the Woodstock Institute ${ }^{48}$ suggest that between thirtytwo percent and sixty percent of properties in foreclosure contain more than one dwelling unit. ${ }^{49}$ The report notes that studies have reinforced the conclusion that the proportion of rentals in foreclosure exceeds twenty percent, particularly in areas with high proportions of renters. 50

Third, low income and minority communities tend to account for a disproportionate percentage of rental foreclosures. ${ }^{51}$ Even though the foreclosure crisis is a national phenomenon, it is especially damaging to low income neighborhoods. "Rental units generally serve lower income households and are concentrated in lower income communities."

44. RealtyTrac is an "online marketplace of foreclosure properties" that "collects and aggregates foreclosure data from more than 2,200 counties, covering more than 90 percent of U.S. households ...." RealtyTrac Backgrounder, REALTYTRAC, http://www.realtytrac.com/ company/backgrounder.html (last visited May 22, 2011).

45. Pelletiere, supra note 41 , at 7.

46. Id. (emphasis added).

47. The Furman Center is an "academic research center devoted to the public policy aspects of land use, real estate development and housing." About the Furman Center, FURMAN CENTER FOR REAL ESTATE AND PUB. POL'Y, http://furmancenter.org/about (last visited May 22, 2011).

48. Woodstock Institute is a "nonprofit research and policy organization in the areas of fair lending, wealth creation, and financial systems reform." About Woodstock Institute, WOODSTOCK INST., http://www.woodstockinst.org/about-woodstock-institute (last visited May 22, 2011).

49. Pelletiere, supra note 41 , at 7.

50. Id. Additionally,

NLIHC has estimated that $32 \%$ of the properties auctioned or bank-owned in four New England states were multifamily properties. In this study, the number in Rhode Island was $41 \%$. A similar study in New York found that $60 \%$ of the filings there contained at least two units. In Chicago, $35 \%$ of the one-to-six unit property foreclosures had at least two units, suggesting that the proportion of multi-unit properties would be even higher if buildings with six or more units were included.

Id.

51. Id. at 8 .

52. $I d$.

53. Id. 
According to data from four New England states, "the foreclosure rate on a per unit basis is more than five times higher in largely non-white, poor neighborhoods than in largely white, low poverty neighborhoods." Roughly sixty percent of foreclosed properties in high-poverty minority neighborhoods are multi-unit buildings, compared to just seven percent in low poverty, white neighborhoods. ${ }^{55}$ There is a clear indication that landlord defaults can have far-reaching impacts on disadvantaged communities.

Fourth, "[t]he foreclosure crisis is exacerbating pre-existing rental market imbalances." 56 The report notes that the current state of the national economy is driving incomes down and forcing more individuals and families into rental housing. ${ }^{57}$ However, the declines in real estate values are providing little, if any, relief to low income renters. ${ }^{58}$ As the number of persons in rental housing increases, so does the pool of potential innocent victims of landlord default situations.

Fifth, "[p]olicies at all levels of government could greatly mitigate the difficulties renters face in foreclosure situations." a direct party to a foreclosure action, they are significantly more likely to become homeless, as compared to actual homeowners. ${ }^{60}$ A gaping deficiency in the common law is exposed when the persons most directly affected by a foreclosure - the actual occupants-are completely at the mercy of forces beyond their control because their participation in the foreclosure proceedings is neither requested nor desired. This lack of involvement impairs the ability of the renters to make alternative housing arrangements, and can precipitate literal homelessness and its associated parade of horribles. Many of these difficulties can be remedied through government involvement.

The NLIHC report's sixth and final finding suggested that, "[t]he federal government has a crucial role to play.,"61 Although real estate law, including foreclosures and evictions, has traditionally been within the purview of state law, the foreclosure crisis is national in scope. ${ }^{62}$ The nation's economy is, for better or worse, intimately intertwined with the nation's housing market; the argument that foreclosures are not the proper subject matter of federal legislation is simply uninformed.

\footnotetext{
54. Id.

55. Id.

56. Id. at 9 .

57. Id.

58. Id.

59. Id. at 10 .

60. Id.

61. Id. at 12 .

62. Id.
} 
These findings distinctly support the conclusion that statutory tenant protections are necessary and justified, especially in the current economic climate. Further, the findings point to the need for action at the federal level, given the national scope of the problem. The harms have devastating potential, the economic ripple effect has far-reaching implications, and the need for reform is obvious. The policy arguments for statutory tenant protections in the United States are clear and powerful.

\section{Policy Arguments for Statutory Tenant Protections in the United Kingdom}

In November 2009, the Council of Mortgage Lenders (CML) ${ }_{64}^{63}$ predicted a large rise in British repossessions compared to previous years. ${ }^{64}$ While Parliament had "introduced several measures aimed at reducing the number of repossessions and assisting households in difficulty to remain in their homes," the measures were not directed toward renters. ${ }^{65}$ It is challenging to account for a precise number of individuals affected by landlord defaults due to the difficulty of collecting statistics on unauthorized tenancies, "those where the landlord has not sought the permission of the lender." 66 Though some tenancies may be binding on the lender, ${ }^{67}$ unauthorized tenancies, ${ }^{87}$ the focus of this Note, generally are not. $^{69}$

63. The CML "is a not-for-profit organisation and the trade association for the mortgage lending industry" in the United Kingdom. About us, CouncIL of MORTGage Lenders, http://www.cml.org.uk/cml/about (last visited May 22, 2011).

64. HOUSE OF COMMONS LIBRARY, RESEARCH PAPER 10/05: MORTGAGE REPOSSESSIONS (Protection of Tenants Etc.) Bill 2 (2010) [hereinafter HC RESEARCH], available at http://www.parliament.uk/briefingpapers/commons/lib/research/rp2010/RP10-005.pdf.

65. Id.

66. $I d$.

67. Id. at 4-6.

68. The British government has described "unauthorised tenancies" as follows: It is a standard term in most owner-occupier mortgages that the borrower is prohibited from renting out the property or that the lender's consent must be sought before any such tenancy is entered into. Where a borrower lets his property in breach of this requirement or related conditions (eg failing to provide required information to the lender) the "tenancy agreement" will be void as against the lender. We refer to these as "unauthorised tenancies." The effect of this is that the "tenant" has no right against the lender to enforce the terms of that agreement. After repossession therefore they will have no right to remain in occupation and no right to notice of termination of the agreement. Even if the "tenants" are aware of possession proceedings and attend the court hearing, the court has very limited powers to take their situation into account.

DEP'T FOR COMMUNITIES AND LOCAL GOV'T, LENDER REPOSSESSION OF RESIDENTIAL Property: Protection of Tenants 11 (2009) [hereinafter English Consultation], available at $\mathrm{http} / / / \mathrm{www} . c 0 m m u n i t i e s . g o v . u k / d o c u m e n t s / h o u s i n g / p d f / 1304815$.

69. HC RESEARCH, supra note 64, at 6. 
Under pre-2010 English law-in-force, landlords could evict month-tomonth tenants without reason and were only required to (1) give a two month notice to vacate and (2) obtain a judicial possession order. ${ }^{70}$ The notice period was designed to provide a necessary "breathing space for tenants to start looking for an alternative home." ${ }^{, 71}$ However, in the case of a defaulting borrower/landlord, the tenant could lose even those basic rights. $^{72}$

Studies suggest that approximately fourteen percent of households in England live in the private rental sector. ${ }^{3 /}$ These tenants are often oblivious to landlord default situations and have no idea they are at risk of losing their homes. ${ }^{74}$ English privacy laws prohibit lenders and solicitors from communicating the details of a default directly to the tenants, and landlords are reluctant to notify tenants for fear of rent payments being withheld. ${ }^{75}$ Often, the only warning the tenant may receive is a hearing notice or notice of eviction addressed to "The Occupier." Occupier" are often treated as junk mail, discarded, or remain unopened for extended periods. ${ }^{77}$ Frequently, despite being current on rent payments, the first indication renters have of a landlord default is the sudden physical presence of bailiffs who have come to take possession of their home.

Even when tenants received adequate notice and attended the possession hearing, the court had no authority to delay the repossession. ${ }^{79}$ "Under these circumstances, tenants are denied the rights they would normally be afforded when a landlord chooses to end a tenancy." ${ }^{80}$ Tenants can also lose out financially when their landlord is repossessed. ${ }^{81}$ Many will never see their deposit returned, and others will likely never recover prepaid rent. ${ }^{82}$ This financial setback can make it even more difficult for the tenant to locate alternative housing.

70. Shelter, Citizens Advice, Crisis \& The Chartered Institute of Housing, A Private MatTer? - Private Tenants: The Forgotten Victims of the Repossessions CRISIS 3 (2009) [hereinafter PRIVATE TENANTS], available at http://england.shelter.org.uk/ data/assets/pdf_file/0003/182532/A_private_matter.pdf.

71. Id.

72. Id.

73. Id. at 1.

74. Id. at 3.

75. Id.

76. Id.

77. Id.

78. HC RESEARCH, supra note 64, at 6.

79. Private Tenants, supra note 70 , at 3.

80. Id.

81. Id. at 4.

82. Id.

83. Id. 
In 2008 , the British Government ordered ${ }^{84}$ an independent study of private rental housing, ${ }^{85}$ referred to as the Rugg Review. The study was completed in October of $2008 .^{86}$ In its formal response to the Rugg Review, the Government included a note on the notice period issue, which stated that the new, longer notice period was a significant improvement from previous practice, but also acknowledged that further action was vital. ${ }^{87}$ In point of fact, "the two months' notice referred to is not a statutory requirement but reflects the time period that may elapse between issue of a claim for possession and the hearing, which [the relevant Civil Procedure Rule (CPR)] sets at four to eight weeks.",88

Some groups, including the Association of Residential Letting Agents (ARLA), ${ }^{89}$ are troubled by the very real possibility that tenants will misinterpret these notices and prematurely break legally binding tenancy agreements. ${ }^{90}$ Other English tenant advocacy groups welcome the CPR changes, but feel they do not go far enough in light of the dismissive treatment given to mail addressed to "The Occupier." open these notices, they are still only provided with short notice of the possession hearing, and do not give the tenants any status in the proceedings or the right to be admitted to the hearing. ${ }^{92}$ Some tenants could even panic and abandon the property immediately, exacerbating the landlord's situation by stopping the rental income. ${ }^{93}$ Finally, the new rules fell short of addressing situations where the formal proceedings are bypassed (for example, where the landlord surrenders the keys to the lender and the tenant is left with no protections whatsoever). ${ }^{94}$

These findings provide solid arguments for statutory tenant protections beyond mere procedural adjustments. These protections are essential to combating the harms of involuntary displacement in the United Kingdom.

84. HC RESEARCH, supra note 64 , at 2.

85. Julie Rugg \& David Rhodes, The U. of York, The Private Rented Sector: Its CONTRIBUTION AND POTENTIAL (2008), available at http://www.york.ac.uk/inst/chp/ publications/PDF/prsreviewweb.pdf.

86. HC RESEARCH, supra note 64 , at 2 .

87. Dep't for Communities and Local Gov't, The Private Rented Sector: Professionalism and Quality: THe Government Response to the RugG REVIEW 26 (2009), available at http://www.communities.gov.uk/documents/housing/pdf/1229922.pdf.

88. HC RESEARCH, supra note 64 , at 3 (emphasis added).

89. The ARLA is "the professional and regulatory body for letting agents in the UK." Company Profile - About Us, Ass'N OF RESIDENTIAL LeTting AGENTS, http://www.arla.co.uk/ about (last visited May 22, 2011).

90. Thomas George, Tenants Could Fall Foul of Law Meant to Protect Them, SouTH WALES ECHO (UK), Aug. 20, 2009, at 3, available at 2009 WLNR 16231935.

91. Private TenanTS, supra note 70 , at 5.

92. Id.

93. Id.

94. Id. 


\section{PART II: STATUTORY TENANT PROTECTIONS IN THE UNITED STATES}

On May 20, 2009, President Barack Obama signed the "Protecting Tenants at Foreclosure Act of 2009" (PTFA) into law. ${ }^{95}$ Senator Christopher Dodd, sponsor of the Senate bill, and Senator John Kerry, the bill's original author, spoke optimistically on the floor of the United States Senate regarding the intent of the legislation. ${ }^{96}$ Senator Dodd noted that the PTFA "protects tenants facing evictions due to foreclosure by ensuring they can remain in their homes for the length of the lease or, at the least, receive sufficient notice and time to relocate their families and lives to a new home." ${ }^{97}$ Senator Kerry stressed the importance of the Federal Reserve and the Department of Housing and Urban Development issuing notifications to their regulated entities because "[f]amilies in these precarious circumstances should not be forced individually to assert their rights under the law." 98

\section{A. The Protecting Tenants at Foreclosure Act of $2009^{99}$}

When the parties and property involved in a foreclosure meet criteria specified in the PTFA, the Act mandates steps that a successor in interest must undertake in order to evict a preexisting tenant (assuming the tenant does not already possess a priority lease). ${ }^{100}$ The Act provides that, in many cases, a tenant may continue to occupy the property until the expiration of the lease. ${ }^{101}$ The Act specifically provides that the successor in interest must provide a "notice to vacate" to any bona fide tenant at least ninety days before the effective date of such notice. ${ }^{102}$ It also states that only a purchaser who will occupy the unit as a primary residence may terminate a lease executed prior to the date of foreclosure filing. ${ }^{103}$ The

95. Protecting Tenants in Foreclosure, U.S. FED. NEwS, June 5, 2009, available at 2009 WLNR 10781368.

96. 155 CONG. REC. S8978 (2009).

97. $I d$.

98. Id.

99. Protecting Tenants at Foreclosure Act of 2009, Pub. L. No. 111-22, §§ 701-704, 123 Stat. $1632(2009)$.

100. Allyson Gold, Note, Interpreting the Protecting Tenants at Foreclosure Act of 2009, 19-WTR J. AFFordable Housing \& COMMUNITY DEv. L. 205, 208 (2010).

101. HR1247: Protecting Tenants at Foreclosure Act of 2009, CRS BILL DiG., May 11,2009, available at 2009 WLNR 9019121. See also Protecting Tenants at Foreclosure: Notice of Responsibilities Placed on Immediate Successors in Interest Pursuant to Foreclosure of Residential Property, Housing \& URB. DEV. DEP'T DOCUMENTS, June 24, 2009, available at 2009 WLNR 12066597.

102. Protecting Tenants at Foreclosure Act $§ \S 701-704$.

103. Id. 
lease continuation provision only applies if: (a) the tenant is not the mortgagor (or the child, spouse, or parent of the mortgagor); (b) the lease or tenancy was the result of an arms-length transaction; and (c) the rent is not substantially less than fair market value (excluding instances of government subsidy). ${ }^{104}$

\section{B. Adequacy of the PTFA}

Supporters claim the law has placed "more power in the hands of renters." 15 However, PTFA opponents argue that the poorly drafted statutory language has introduced confusion and uncertainty that is fueling compliance litigation against lenders. ${ }^{106}$ There are many legitimate criticisms of the PTFA that illuminate the need for amendments to the Act.

Statutory ambiguity is a common theme among critics. Complicating the matter, "no federal agency has authority to issue regulations implementing the law or to interpret the law." 107 The Affordable Housing Task Force aptly notes that, "[a]s with all new laws, [the PTFA] is open to interpretation. Until a court decides exactly what this law means, we can only do our best to interpret it." 108

Even state legislatures found themselves struggling to interpret the new statute. A Florida legislative report posited the following questions:

- Is the landlord required to pursue an eviction action after the 90 days?

- What information should be included in the 90-day notice?

- Is the tenant still required to pay rent and to whom?

- Does the tenant have an obligation to stay?

- Does the property manager have any ongoing obligation to the property?

- What happens with the security deposit? ${ }^{109}$

104. Id.

105. Nirvi Shah, New Law Gives Tenants More Clout in Cases of Foreclosure, MiamI HERALD, August 23, 2009, at E1, available at 2009 WLNR 16426073.

106. Elizabeth Stull, Credit Crisis Driving Securities, Mortgage-Related Litigation, DAILY REC. (Rochester, NY), Aug. 28, 2009, available at 2009 WLNR 17035582.

107. Letter from Sandra F. Braunstein, Director, Division of Consumer and Community Affairs, Board of Governors of the Federal Reserve System, to The Officers and Managers in Charge of the Consumer Affairs Divisions (July 30, 2009), available at http://www.federalreserve.gov/boarddocs/caletters/2009/0905/caltr0905.htm.

108. AfFordable Housing TASK FORCE, KNOW YOUR RIGHTS! RENTERS IN FORECLOSURE 4 (2009), available at http://www.miamidade.gov/foreclosure/library/ Know_Your_Rights_Handbook.pdf.

109. The Florida Senate, Committee on Judiciary, Tenants' Rights IN FORECLOSURE ACTIONS, INTERIM REP. 2010-124, 7 (2009), available at http://www.flsenate.gov/data/Publications/2010/Senate/reports/interim_reports/pdf/2010-

124ju.pdf (bullets in original). 
The PTFA is vague or silent on numerous other matters, including whether the protections continue if a tenant is late on payments. ${ }^{110}$ Lenders who acquire properties via foreclosure sale are struggling to comply with the PTFA "because it doesn't specify between tenants who have been paying rent and those who have not." ${ }^{111}$ The injustice of involuntary displacement, a primary policy argument in favor of statutory tenant protections, is certainly diminished if the tenant is no longer an innocent party; however, courts are likely to see litigation on this very point.

The PTFA also does not address the status of existing lease agreements when property acquired by institutional purchasers at the foreclosure sale is immediately re-sold in a flip transaction to a new owneroccupier. ${ }^{112}$ The Act is silent on whether this subsequent owner-occupier (who will inhabit the unit as a primary residence) may terminate an existing lease prior to its natural expiration as if the new owner-occupier had purchased the property directly at the foreclosure sale. The fact that the PTFA carves out an exception to allow primary residence purchasers to terminate existing leases suggests that Congress finds tenant rights subordinate to owner-occupier-purchaser rights, generally. If correct, this position implies that any successor in interest who will occupy the unit as a primary residence can terminate the lease. This is yet another ambiguity that invites stakeholders to flood courts with litigation in order to obtain an interpretation of the statute.

Additionally, the statute does not address whether the ninety-day notice can be given prior to the foreclosure sale. ${ }^{113}$ The language requires the "immediate successor in interest" to provide the notice. ${ }^{14}$ What happens if the foreclosure Plaintiff purchases the property-would a presale notice from the Plaintiff satisfy the statute? At least one public interest group suggests that any ninety-day notice sent prior to the legal transfer of title is ineffective. ${ }^{115}$ Indeed, a pre-sale notice would seem to circumvent the entire protective mechanism intended by the notice provision.

110. Tom Bayles, New Law Protects Renters, Sarasota Herald Tribune (FL) (June 22, 2009, 1:00 AM), http://www.heraldtribune.com/article/20090622/COLUMNIST/ 906221013.

111. Jerry DeMuth, Creating Chaos, Mortgage BANKIng, Oct. 1, 2009, at 64, available at 2009 WLNR 22520863.

112. Bayles, supra note 110 . The term "flip" means "[t]o buy and then immediately resell ... real estate in an attempt to turn a profit." BLACK's LAW DiCTIONARY (9th ed. 2009) (West).

113. Frank S. Alexander, Georgia Real Estate Finance and Foreclosure law $\S 8.8(2011)$.

114. Protecting Tenants at Foreclosure Act of 2009, Pub. L. No. 111-22, §§ 701-704, 123 Stat. 1632 (2009).

115. Pub. Justice Ctr., Tenants and Foreclosure Procedure in Maryland 6-7 (2009), available at http://publicjustice.org/publicjustice/uploads/File/Renters_and_ Foreclosure_In_MD_09Dec21--_PUBLIC.pdf. 
However, the answer may vary between jurisdictions depending on whether the state subscribes to a title, lien, or intermediate theory of property. ${ }^{116}$

The lease continuation provision is also unclear; is this an option the tenant can elect, or does the lease continue in force as a matter of law postforeclosure? $?^{117}$ If the lease continues as a matter of law, it would potentially give rise to a cause of action by the immediate successor in interest against the tenant if the tenant vacates the property without paying the full ninety-day rent. ${ }^{118}$ Given the possibility that renters will voluntarily vacate the premises after receiving a notice of foreclosure, this outcome seems severe. Once again, this is a matter likely to drive parties into courts across the nation, and to result in a patchwork of widely varied interpretations.

The PTFA left many unanswered questions, and courts, with minimal substantive guidance, will likely be asked to resolve these issues. As discussed below in Part IV, lawmakers can take steps to minimize the significant strain on judicial resources, and reduce the considerable stakeholder confusion and instability, created by these ambiguities.

\section{Post-PTFA State Responses}

States are also closely watching the PTFA with regard to their own policy initiatives. ${ }^{119}$ One of the most obvious concerns of state lawmakers is preemption-whether the PTFA trumps state law in any given jurisdiction. ${ }^{120}$ The Supremacy Clause of the United States Constitution states that federal laws "shall be the supreme law of the land." 21 Generally speaking, if the PTFA provides greater protection, it preempts state law; however, if state law provides greater protection, state law prevails. ${ }^{12}$ Legislators are struggling to understand the contours of the PTFA in order to define what could constitute greater or lesser protection.

116. Gold, supra note 100 , at 213-14.

117. ALEXANDER, supra note 113.

118. See Gold, supra note 100, at 213-14.

119. See, e.g., THE FLORIDA SENATE, supra note 109.

120. See Gold, supra note 100, at 216-17.

121. U.S. CONST. art. VI., cl. 2.

122. GMAC Mortgage, LLC v. Taylor, 899 N.Y.S.2d 802, 805 (D.Ct. Suffolk Co., Dist. 3, Mar. 1, 2010) (noting that while the Supremacy Clause of the U. S. Constitution mandates the preemption of state laws in conflict with federal law, "the provisions of 12 USC Sec. 5220 Note (a)(2)(A) are self exempting and inapplicable as the statute expressly limits its reach in subdivision (a) when it provides: 'Except that nothing under this section shall affect the requirements for termination of any Federal or State subsidized tenancy or of any State or local law that provides longer time periods or other additional protections for tenants.' Emphasis added."). 
The Florida legislature is pursuing a wait-and-see strategy regarding statutory tenant protections. ${ }^{123}$ Lawmakers want to determine whether Congress will re-enact or otherwise extend the PTFA beyond its December 31, 2012 expiration date. ${ }^{124}$ Meanwhile, other states are taking more proactive measures in combating the ills of involuntary displacement of tenants. ${ }^{125}$ There is concern among some Florida legislators that premature state action risks irritating an already critical housing situation in the sunshine state.

On December 15, 2009, New York's Governor, David Paterson, "signed into law comprehensive foreclosure legislation which provides additional critical protections for New York State homeowners, tenants and neighborhoods in the wake of the ongoing foreclosure crisis." 126 The bill adds to a 2008 subprime lending reform law by "assisting homeowners currently at risk of foreclosure and minimizing the negative impacts that foreclosures have on communities." ${ }^{127}$ The law became effective January 14,2010 , and contains lease extension and ninety-day notice provisions similar to the PTFA. ${ }^{128}$ New York took a proactive approach and enacted a PTFA-like statutory tenant protection scheme of its own in order to provide protections that are independent of the whims of Congress.

In California, over a dozen cities have ratified a patchwork of various eviction control laws. ${ }^{129}$ A proposal, known as the "California Tenant Stability Act," purports to standardize and strengthen eviction control measures by promoting a statewide law limiting evictions, governing security deposits, regulating notice, increasing private representation of tenants, and funding education and outreach programs. ${ }^{130}$ The California plan takes a more comprehensive view of the problems associated with involuntary displacement.

Arguably, however, the most tenant-friendly protections in the United States are of the variety available in Massachusetts. There, the legislature enacted a law in 2010 that prevents a foreclosing owner from evicting a tenant "except for just cause."131 This approach benefits tenants by allowing them to retain pre-foreclosure lease terms without interruption. However, the marginal additional benefit to tenants is offset by significant

123. The Florida SENATE, supra note 109 , at 8.

124. Id.

125. See, e.g., Gov. Paterson Signs Comprehensive Foreclosure Legislation into Law, U.S. FED. NEWS, Dec. 16, 2009, available at 2009 WLNR 25272024.

126. Id.

127. Id.

128. N.Y. REAL PROP. ACTS. LAW $\S 1305$ (McKinney 2010).

129. Nicole Gon Ochi, Note, The California Tenant Stability Act: $A$ Solution for Renters Affected by the Foreclosure Crisis, 17 GEO. J. ON POVERTY L. \& POL'Y 51, 65 (2010).

130. Id. at 65-76.

131. MASS. GEN. LAWS ANN. ch. 186A, $\S 2$ (West 2010). 
additional detriments to the other stakeholders, including: (1) purchasers intent on becoming owner-occupiers are forced into becoming long-term landlords, which (2) discourages potential buyers from even attending foreclosure sales, which (3) drives down the sale proceeds collected from the auction, and (4) saddles the mortgagor with a higher deficiency debt. For any statutory tenant protection arrangement, the goal should be to mitigate the harms of involuntary displacement. However, given its significant disadvantages, the Massachusetts policy likely goes too far.

This potpourri of state and local statutory tenant protection schemes only serves to intensify the stakeholder uncertainty surrounding the PTFA. There is no better time for Congress to implement uniform statutory tenant protections. Legislators should be inspired by the significant public support for such measures, as evidenced by the sheer number of state and local responses, and work to enact permanent and comprehensive legislation to protect tenants from unscrupulous landlords.

\section{The Future of Statutory Tenant Protections at the Federal Level}

Calls have been made for a more expansive version of the PTFA that would require the immediate successor in interest to give former borrowers the right to enter into long-term leases on properties they have lost to foreclosure. ${ }^{132}$ Supporters contend that this rental option is a solution that provides no windfalls to borrowers (since they lose ownership of their homes), minimizes disruptions to neighborhoods, and requires no taxpayer money. ${ }^{133}$

Critics of this proposal argue that the hassle of property management inappropriately jumps the wall between finance and commerce. ${ }^{134}$ As one finance executive notes, "[n]o bank wants to be a landlord."135 A forced landlordship confers responsibility for property upkeep (maintenance, taxes, HOA fees, lawn care, etc.) on the former lender. ${ }^{136}$ The significant expense required for such an enterprise foretells a momentous lobbying pushback from the banking industry, and renders this type of expansion of the PTFA highly unlikely.

A 2009 report by seven of the leading homelessness and housing advocacy groups in the United States (the National Coalition for the Homeless, the National Alliance to End Homelessness, the National Association for the Education of Homeless Children and Youth, the National Health Care for the Homeless Council, the National Law Center

132. Harry Terris, GSEs Find Seized Homes Easier to Empty than Rent, AM. BANKER, October 14, 2009, at 1, available at 2009 WLNR 20212557.

133. Id.

134. Id.

135. Id.

136. Id. 
on Homelessness \& Poverty, the National Low Income Housing Coalition, and the National Policy and Advocacy Council on Homelessness) recognized that the PTFA does "not completely-or permanently-resolve the underlying lack of tenant rights." 37 The report makes several recommendations regarding the protection of renters, including that PTFA "provisions become permanent protections that extend beyond 2012."138 Further, the groups ask that:

B. Renters in foreclosed units utilizing other federal, state or local subsidies should receive the same protection that Section 8 voucher holders have been granted under the new law. C. Local policies should ensure that foreclosed properties are maintained by the owner, lender and/or jurisdiction in such a condition that they are suitable for habitation by tenants who are legal occupants. ${ }^{139}$

Some members of Congress agree that PTFA protections should become permanent fixtures in federal law. ${ }^{140}$ On March 4, 2010, Representative Keith Ellison, a Democrat from Minnesota, introduced H.R. 4766, the "Permanently Protecting Tenants at Foreclosure Act of 2010." This bill would have repealed the sunset provision of PTFA and made the law permanent. ${ }^{141}$ However, Representative Ellison was not successful in this endeavor and the sunset provision remains.

The PTFA makes significant strides in providing security of tenure for renters, and state activity in this arena indicates considerable popular support for permanent tenant protections. However, making the PTFA permanent would merely be a good start. Without significant amendments and clarifications, the PTFA will never fully realize its potential to comprehensively protect innocent tenants from the harms of involuntary displacement.

137. National Coalition for the Homeless, et al., Foreclosure to Homelessness 2009: THE ForgotTEN VICTIMS OF THE SUBPRIME CRISIS 8 (2009) [hereinafter VICTIMS], available at http://www.nationalhomeless.org/advocacy/ForeclosuretoHomelessness 06 09.pdf.

138. Id. at 16 .

139. Id.

140. Permanently Protecting Tenants at Foreclosure Act of 2010, H.R. 4766, 111 th Cong. (2010) (noting multiple co-sponsors), available at http://www.gpo.gov/fdsys/pkg/BILLS$11 \mathrm{hr} 4766 \mathrm{ih} / \mathrm{pdf} / \mathrm{BILLS}-111 \mathrm{hr} 4766 \mathrm{ih} . \mathrm{pdf}$.

141. Id. 


\section{PART III: STATUTORY TENANT PROTECTIONS IN THE UNITED KINGDOM}

Recognizing the need for legislative action, the English Government called for an official Consultation to identify the specific problems of tenants in repossession actions and to identify workable solutions. In calling for the Consultation, Housing Minister John Healey noted, "[i]t is wrong that through no fault of their own these families can find themselves out on the street." ${ }^{142}$ Minister Healey sought to examine possible "safeguards for tenants of dodgy landlords who leave them vulnerable to eviction with little notice."

The Consultation was completed in August 2009 and considered five courses of action. ${ }^{144}$ The first option considered retention of the status quo. ${ }^{145}$ The second examined the possibility of giving "unauthorised tenants the right to be heard at the possession hearing," and empowering courts to postpone repossession in order to allow tenants a reasonable period of time to move. ${ }^{146}$ The third option dealt with amending "the notification of the possession hearing, so that more unauthorised tenants attend and make representations at the hearing." ${ }^{\text {"147 }}$ The fourth option would require "lenders to notify their intention to enforce possession, and provide a mechanism for unauthorised tenants to request a two-month delay." 148 The final alternative explored provision of "a mechanism for unauthorised tenants to request a two-month stay in the warrant of possession." 149

Ultimately, the Consultation urged the government to adopt a hybrid solution allowing tenants to be heard at repossession hearings, giving courts the power to delay proceedings, and requiring a new notice of intent to enforce possession along with a mechanism for tenants to apply for a twomonth reprieve. ${ }^{150}$ Although the cost of implementing such changes is estimated at $£ 19.2 \mathrm{M}$ over the next ten years, the monetary benefit outweighs the cost and justifies the expenditure. ${ }^{151}$ In addition, there would be considerable non-monetary benefits to the public at large as a result of

142. Joe Murphy, New Rights Over Eviction for Tenants of Bad Landlords, EvENING STANDARD (London, UK), Aug. 6, 2009, http://www.thisislondon.co.uk/standard/article23728954-new-rights-over-eviction-for-tenants-of-bad-landlords.do.

143. Id.

144. ENGlish CONSUltation, supra note 68 , at 5, 7.

145. Id. at 7.

146. Id.

147. Id.

148. Id. (emphasis added).

149. Id. (emphasis added).

150. Id.

151. Id. at 31,35 . 
reduced stress and disruption caused by short-notice evictions. ${ }^{152}$

After the Consultation was completed, 126 members of Parliament signed "EDM 1154" regarding "Tenants in the Private Rented Sector and Repossessions," which stated:

That this House recognises that tenants in the private rented sector risk losing their homes through repossession when landlords default on mortgages; notes that many tenants are evicted with little or no notice, sometimes only finding out when the bailiff arrives on their doorstep; further notes that many of these tenants could be at risk of homelessness through no fault of their own; and calls on the Government to take urgent action to avert a potential crisis by giving courts the discretion to defer possession and allow tenants sufficient time to find another home. ${ }^{153}$

Then, on December 16, 2009, before the Consultation's stakeholder comment period closed, Dr. Brian Iddon, MP, introduced "a Bill to protect private tenants from losing their homes in the event of their landlord defaulting on the mortgage payments." 154 The Bill was titled the Mortgage Repossessions (Protection of Tenants Etc) Bill. ${ }^{155}$

\section{A. The Mortgage Repossessions (Protection of Tenants etc) Act $2010^{156}$}

Dr. Iddon's Bill was approved by both houses of Parliament, received Royal Assent on April 8, 2010, ${ }^{157}$ and took effect on October 1, 2010. ${ }^{158}$

152. Id. at 7 .

153. Id at 9 . See House of COMMONS Info. OfFice, Factsheet P3: Early Day Motions 1 (2008), available at http://www.parliament.uk/documents/commonsinformation-office/p03.pdf ("Early day motion (EDM) is a colloquial term for a notice of motion given by a Member for which no date has been fixed for debate. EDMs exist to allow Members to put on record their opinion on a subject and canvass support for it from fellow Members. In effect, the primary function of an EDM is to form a kind of petition that MPs can sign and there is very little prospect of these motions being debated on the floor of the House.").

154. HC RESEARCH, supra note 64 , at 12.

155. Mortgage Repossessions (Protection of Tenants Etc.) Bill, 2009-10, H.C. Bill [15] (Eng. \& Wales), available at http://www.publications.parliament.uk/pa/cm200910/cmbills/ 015/2010015.pdf.

156. Mortgage Repossessions (Protection of Tenants etc) Act, 2010, c. 19 (Eng. \& Wales), available at http://www.legislation.gov.uk/ukpga/2010/19/enacted/data.pdf.

157. Bill Progress: Mortgage Repossessions (Protection of Tenants Etc.) Bill 2009-10, U.K. PARLIAMENT, http://services.parliament.uk/bills/2009-10/mortgagerepossessions protection oftenantsetc.html (last visited May 22, 2011). See generally HousE OF COMMONS INFORMATION OfFICE, PARLIAMENTARY STAGES OF A GOVERNMENT BILl (2010), available at http://www.parliament.uk/documents/commons-information-office/101.pdf (a primer on 
The Mortgage Repossessions (Protection of Tenants etc) Act 2010 (MRPTA) has two substantive clauses. ${ }^{159}$ The first addresses the power of the court to postpone repossession, and the second deals with notice of the intended repossession. ${ }^{160}$

The MRPTA applies to dwelling units as well as mixed-use residential/commercial property. ${ }^{161}$ The Act generally covers unauthorized tenancies with annual rents of up to $£ 100,000 .^{162}$ High-value residential tenancies, those in excess of the $£ 100,000$ per year mark, are excluded from protection under the Act, and tenants in these situations are not included in the statutory protection scheme. ${ }^{163}$

The first substantive section of the MRPTA, in essence, provides the court with wide discretion to give tenants a two-month period to locate alternative housing. ${ }^{164} \mathrm{~A}$ tenant may make application for this accommodation either before the possession order is granted, in which case the court could delay the date of the possession order, or after the possession order is granted, in which case the court may stay or suspend the execution of the order. ${ }^{165}$

Clause 1(5) of the MRPTA requires courts to contemplate certain enumerated criteria when examining tenant requests for reprieve from possession orders. ${ }^{166}$ The court must duly consider the unique circumstances of the tenant. ${ }^{167}$ If the tenant is currently in breach of the lease agreement, the court must weigh the nature of the breach and the ease with which it could have been avoided. ${ }^{168}$ The delay or stay "may be made conditional upon the tenant making payments to the mortgagee in respect of their occupation during that period." 169 However, as Clause 1(7) makes

U.K. legislative process). The author recognizes the publication addresses government bills, and the MRPTA was technically a private bill; however, the general overview may be helpful to those unfamiliar with how bills become laws in the United Kingdom.

158. Mortgage Repossessions (Protection of Tenants etc) Act 2010 (Commencement) Order, 2010, S.I. 2010/1705 (Eng. \& Wales), available at http://www.legislation.gov.uk/ uksi/2010/1705/made/data.pdf.

159. Mortgage Repossessions (Protection of Tenants etc) Act, 2010, c. 19 (Eng. \& Wales).

160. Teresa Sutton, Legislative Comment: The Mortgage Repossessions Bill, 14(2) LANDLORD \& TENANT REV. 48, 49-50 (2010).

161. Sophie Schultz, Residential Repossession and Unauthorised Tenants, ALLEN \& OVERY (Sept. 1, 2010), http://www.allenovery.com (web page no longer available; archived copy on file with author).

162. Andy Creer, Mortgage Repossessions and Tenants, HARDWICKE (Sept. 27, 2010), http://www.hardwicke.co.uk/articles/mortgage-repossessions-and-tenants.

163. Schultz, supra note 161.

164. Id.

165. Creer, supra note 162.

166. Sutton, supra note 160 , at 49 .

167. Id.

168. Id.

169. Id. 
clear, such payments would not serve as evidence of a newly created tenancy. ${ }^{170}$

The second substantive section of the MRPTA provides that possession orders can only be executed after the mortgagee has given notice, at the property, of the intention to repossess. ${ }^{171}$ The regulations provide that fourteen days must elapse between service of the notice and execution of the warrant. ${ }^{172}$ The hope is that the new requirements will increase the chances that a tenant will apply for a stay or delay of the possession order. ${ }^{173}$

\section{B. Adequacy of the MRPTA}

Several key stakeholders in the housing industry strongly supported allowing tenants the opportunity to be heard at a possession hearing. ${ }^{174}$ There was near unanimous agreement that this type of legislative action was prudent; however, there was much less agreement, particularly from the mortgage industry, on allowing tenant applications for postponement of possession orders. ${ }^{175}$ The Council of Mortgage Lenders (CML) vehemently disagreed with the postponement provision, claiming that it unfairly prejudiced lenders. ${ }^{176}$ The Council noted that the postponement provision places a new, and significant, burden upon lenders, and that the burden is inequitable given that the need for repossession only arises through borrower breach. ${ }^{177}$ Similarly, the Building Societies Association (BSA) opposed the postponement provision claiming that it unjustly punishes lenders, who, like tenants, may be innocent. ${ }^{178}$ The BSA was troubled by the notion of lenders acting as landlords and the significant transaction costs involved with the involuntary creation of this new relationship. ${ }^{179}$

170. Id.

171. Id. at 50 .

172. The Dwelling Houses (Execution of Possession Orders by Mortgagees) Regulations, 2010, S.I. 2010/1809 (Eng. \& Wales), available at http://www.legislation.gov.uk/ uksi/2010/1809/pdfs/uksi_20101809_en.pdf.

173. Sutton, supra note 160 , at 50 .

174. HC RESEARCH, supra note 64 , at 10.

175. Id.

176. COUNCIL OF MORTGAGE LeNDERS, LENDER REPOSSESSION OF RESIDENTIAL Property: Protection of Tenants, Response by the CoUnCIL of Mortgage Lenders to THE COMMUNITIES AND LOCAL GOVERNMENT CONSUlTATION PAPER 1 (2009), available at $\mathrm{http} / / \mathrm{www} . \mathrm{cml}$.org.uk/cml/filegrab/Lenderrepossessionofresidentialpropertyprotectionoften ants.pdf?ref=6895.

177. Id.

178. Press Release, Building Societies Association, CLG Consultation on Lender Repossession of Residential Property: Protection of Tenants, Response by the BSA (Oct. 13, 2009), http://www.bsa.org.uk/members/policybrief/CLG_consultation_unauthoris ed_tenants.htm.

179. Id. 
The MRPTA language has created some confusion regarding the postponement provision: stakeholders are uncertain of whether a tenant may request both a pre-order delay and a post-order stay. If so, this would permit the tenant to "double dip" and obtain postponement for up to four months, as opposed to two months as originally contemplated in the Consultation. ${ }^{180}$ "Dr. Iddon was confident that the Bill would be interpreted by the courts to mean that only one suspension of a possession order would be possible." over the accuracy of Dr. Iddon's statement. ${ }^{182}$ When a landlord fully complies with the terms of a delayed possession order, but arrears subsequently accrue, the plain reading of the statute and Guidance suggests that the tenant could, in fact, apply for a stay of possession regardless of whether the original order has "fallen away." 83 These conflicting interpretations are likely to give rise to litigation.

\section{The Future of Statutory Tenant Protections in the United Kingdom}

Unlike the PTFA in the United States, the MRPTA does not contain an expiration date or "sunset provision." "184 This signals the Government's commitment to providing permanent protection for tenants. Additionally, the MRPTA has generally received a warm welcome among stakeholders in the United Kingdom, and its passage was referred to as a "no brainer." 185 However, a number of advocacy groups, including Crisis, Shelter, and the Residential Landlord's Association, have called for more comprehensive statutory tenant protections.

Crisis, the England-based national charity for single homeless people, ${ }^{186}$ generally supports the changes included in the MRPTA. ${ }^{187}$

180. Sally Blackmore, "Very Much for the Public Good": A Consideration of the Mortgage Repossessions (Protection of Tenants etc) Act 2010, 14(1) J. Housing L. 12, 13 (2011).

181. House of COMmons LibraRy, Research Paper 10/15: MoRTgage Repossessions (Protection of Tenants Etc.) Bill: Committee Stage RePort 3 (2010) [hereinafter HC COMMITTEE], available at http://www.parliament.uk/briefingpapers/commons/lib/research/rp 2010/RP10-015.pdf.

182. Blackmore, supra note 180 , at 13-15. See DeP'T FOR COMMUNITIES AND LoCAL Gov't, Guidance to the Mortgage Repossessions (Protection of Tenants etc) ACT 201019 (2010) [hereinafter GUIDANCE], available at http://www.communities.gov.uk/ documents/ housing/pdf/1729687.pdf.

183. Blackmore, supra note 180 , at 13-15.

184. See Mortgage Repossessions (Protection of Tenants etc) Act, 2010, c. 19 (Eng. \& Wales), available at http://www.legislation.gov.uk/ukpga/2010/19/enacted/data.pdf.

185. Blackmore, supra note 180, at 12.

186. Crisis (charity), WIKIPEDIA, http://en.wikipedia.org/wiki/Crisis_(charity) (last visited May 22, 2011).

187. Crisis, Lender Repossession of Residential Property: Protection of Tenants, CRISIS'S RESPONSE to THE CLG CONSULTATION 1 (2009) [hereinafter CRISIS RESPONSE], 
However, the group would like to see a provision for positive referral to the court on any dispute between lenders and tenants regarding their applications for continued tenancy. ${ }^{188}$ Crisis notes that such protection would encourage lenders to carefully consider applications and discourage tenants from making fraudulent claims. ${ }^{189}$

Shelter, a British charity that campaigns to end homelessness and bad housing, ${ }^{190}$ has also called for additional statutory tenant protections. ${ }^{191}$ The group recommends taking the onus away from the tenant to make an appeal, and instead placing an obligation on the lender to notify the court when it denies an application for the two-month delay. ${ }^{192}$ Shelter further calls for an affirmative right to request an extension of the fourteen-day delay period in extraordinary situations where the tenant may have been out of the country or in the hospital. ${ }^{193}$ Finally, the group recommends allowing all tenants, regardless of whether they are behind on rent payments, to apply for the two-month delay, suggesting that this would achieve parity with tenants who are evicted by a landlord. ${ }^{94}$

The Residential Landlord's Association (RLA) also generally supports the MRPTA, but recommends adding a number of provisions. ${ }^{19}$ The RLA believes that "[w]here a suspended possession order is made in the case of a tenanted property then there should be an obligation imposed on the lender to return to Court to seek the Court's permission to enforce the order." 196 The RLA also believes that "all existing tenancies," regardless of whether they are authorized or not, should "bind the mortgage lender ... according to the terms agreed with the landlord up to a maximum of 12 months." 197

The MRPTA is a significant improvement over the common law in terms of providing security of tenure to renters and has significant support from stakeholders on all flanks of the issue. However, without more, the

available at http://www.crisis.org.uk/data/files/publications/0910Landlord\%20repossessions $\% 20$ consultationFINAL.pdf.

188. Id. at 4 .

189. Id.

190. Shelter (charity), WIKIPEDIA, http://en.wikipedia.org/wiki/Shelter_(charity) (last visited May 22, 2011).

191. SHELTER, SHELTER'S RESPONSE TO THE COMMUNITIES AND LOCAL GOVERNMENT Consultation - Lender Repossession of Residential Property: Protection of TENANTS 3 (2009) [hereinafter SHELTER RESPONSE], available at http://england. shelter.org.uk/_data/assets/pdf_file/0003/219882/10-09_Lender_repossession_-_Protection of tenants.pdf.

192. Id. at 8 .

193. Id. at $8-9$.

194. Id. at 9.

195. Press Release, Residential Landlords Association, Response to CLG's Consultation Paper - Lender Repossession of Residential Property: Protection of Tenants (Jan. 19, 2010), http://news.rla.org.uk/index.php/archives/date/2010/01/page/13.

196. Id.

197. Id. 
MRPTA is not sufficient to universally protect innocent tenants, and society at large, from the harms of involuntary displacement.

\section{PART IV: RECOMMENDATIONS}

"'Home' is a powerful and rich word in the English language. As our cultural cliché 'a house is not a home' suggests, 'home' means far more than a physical structure. 'Home' evokes thoughts of, among many other things, family, safety, privacy, and community." common law fails to fully safeguard the sanctity of homestead for renters, statutory enactments are necessary to protect society and individuals alike from the innumerable harms of involuntary displacement.

\section{A. Recommendations for the United States Congress}

First and foremost, Congress should make the protections of the PTFA permanent. The substantial harms of involuntary displacement, especially among the most vulnerable renters, will not suddenly evaporate when the Act expires. There is significant support from multiple advocacy groups for repeal of the sunset provision. ${ }^{199}$ As noted earlier, Representative Ellison has already sparked discussion of making the PTFA permanent. ${ }^{200}$ Members of Congress should harness the momentum of public opinion and act quickly to ensure statutory tenant protections do not expire, especially in the midst of a global economic downturn.

Another major flaw of the PTFA is the absence of administrative oversight in the law's execution. Although Congress had the power to do so, ${ }^{201}$ it did not delegate rulemaking authority over the PTFA to any administrative agency. ${ }^{202}$ Given the numerous ambiguities that have been exposed since the Act's passage, ${ }^{203}$ Congress must amend the PTFA to authorize an administrative agency, specifically the Department of Housing and Urban Development (HUD), to resolve ambiguities in the PTFA. HUD is uniquely qualified to address matters of housing policy, ${ }^{204}$ and its

198. Barros, supra note 25 , at 255.

199. E.g., VICTIMS, supra note 137.

200. Permanently Protecting Tenants at Foreclosure Act of 2010, H.R. 4766, 111 th Cong. (2010), available at $\mathrm{http} / / / \mathrm{www} . g p o . g o v / \mathrm{fdsys} / \mathrm{pkg} / \mathrm{BILLS}-11 \mathrm{hr} 4766 \mathrm{ih} / \mathrm{pdf} / \mathrm{BILLS}-111 \mathrm{hr}$ 4766ih.pdf.

201. "The Constitution authorizes the delegation of rulemaking to agencies because Congress is given the power ' $[\mathrm{t}] \mathrm{o}$ make all laws which shall be necessary and proper' to carry out its functions under Article I. U.S. Const. art. I, § 8." WILLIAM F. FUNK ET. AL., AdMINISTRATIVE Procedure AND PRACTICE 520 (4th ed. 2010).

202. See Protecting Tenants at Foreclosure Act $\S 702(a)(1)$.

203. See supra Part II.B.

204. See Mission, U.S. DEP'T OF HousING AND URBAN DEV., http://portal.hud.gov/ hudportal/HUD?src=/about/mission (last visited May 22, 2011) ("HUD's mission is to create 
resources should be utilized to strengthen the PTFA, protect tenants, and improve judicial economy.

Whether by direct legislation or administrative delegation, Congress must act to eliminate ambiguities in the PTFA. Specifically, the text of the ninety-day notice provision ${ }^{205}$ should be clarified to prohibit notices sent prior to the foreclosure sale in attempts to thwart the ninety-day period. The use of this loophole subverts the purpose of the law, and an authoritative interpretation would prevent abuse. This single ambiguity has caused much needless confusion among stakeholders, ${ }^{206}$ and clarification would reduce unnecessary litigation.

Additionally, the lease extension provision ${ }^{207}$ must address tenant discontinuation of rent payments. The Act should be amended (or interpreted by an agency) to allow foreclosure sale purchasers to initiate normal eviction proceedings upon tenant default. Uncertainty on this point has generated confusion for potential foreclosure sale purchasers. ${ }^{208} \mathrm{~A}$ definitive assertion in this regard would add stability to the housing and lending markets. Additionally, the role of the lease extension provision ${ }^{209}$ in flip transactions must be defined. Institutional purchasers should be required to sell flipped properties "subject to priority lease," which would place post-foreclosure flip transactions on a level playing field with all other flip transactions.

Congress should also take notes from the British playbook ${ }^{210}$ regarding the notice provisions of the PTFA. ${ }^{211}$ More precisely, the PTFA needs statutory clarification or administrative guidance to regulate the content of these notices. The imprecise requirements of the current PTFA have given rise to divergent interpretations and practices, but standardized content would impose fairness and congruity in the foreclosure process. ${ }^{212}$ To be more exact, the notice would be significantly more helpful to tenants if it included information "about [the tenant's] rights and where they can go to get further advice." 213

strong, sustainable, inclusive communities and quality affordable homes for all. HUD is working to strengthen the housing market to bolster the economy and protect consumers; meet the need for quality affordable rental homes; utilize housing as a platform for improving quality of life; build inclusive and sustainable communities free from discrimination; and transform the way HUD does business.").

205. Protecting Tenants at Foreclosure Act of $2009 \S 702$ (a)(1), Pub. L. 111-22, Div. A., May 20, 2009, 123 Stat. 1632.

206. See ALEXANDER, supra note 113.

207. Protecting Tenants at Foreclosure Act $\S 702(a)(2)$.

208. See Bayles, supra note 110; DeMuth, supra note 111 .

209. Protecting Tenants at Foreclosure Act $\S 702(a)(2)$.

210. See ENGLISH Consultation, supra note 68.

211. Protecting Tenants at Foreclosure Act of 2009, Pub. L. No. 111-22, $\S 702$ (a)(1), 123 Stat. 1632 (2009).

212. See THE FlORIDA SENATE, supra note 109 , at 3 .

213. Private Tenants, supra note 70 , at 6. 
Overall, the PTFA grants renters significantly more protections than its British counterpart. However, the lack of administrative delegation and temporary nature of the Act are glaring deficiencies in the PTFA that prevent it from fully recognizing its potential to eliminate or mitigate the harms of involuntary displacement of otherwise innocent renters.

\section{B. Recommendations for the United Kingdom Parliament}

Parliament should take steps to refine the MRPTA and implement suggestions ${ }^{214}$ from key stakeholders. The Bill was prematurely introduced before Parliament received the summary report of stakeholders' input. ${ }^{215}$ Now, Parliament has the opportunity to construct a more comprehensive, highly effective piece of tenant protection legislation by examining stakeholder proposals and implementing a number of suggestions contained therein.

Explicitly, Parliament should amend the MRPTA to require lender denials of postponement requests to be immediately submitted to the court for judicial determination. ${ }^{216}$ This would encourage careful lender consideration of tenant applications and remove the burden of filing an appeal from the tenant. ${ }^{217}$ As Senator Kerry noted, fairness demands that families not be burdened with an affirmative duty to assert their rights; Parliament should heed this assertion and provide British families with commensurate procedural protections.

Additionally, regulations should be promulgated to allow the inclusion of delinquent renters in the delay request program, except under the most extreme circumstances of fraud or wrongdoing. ${ }^{219}$ This would place all renters on a level playing field since non-repossessed renters, delinquent or not, can avail themselves of the benefit of a delay. ${ }^{220}$ It hardly seems just to punish tenants who simply have "dodgy" landlords, and the matter is easily remedied.

Alternatively, and preferably, Parliament should enact a provision similar to the PTFA's lease extension provision. ${ }^{221}$ If the MRPTA were to include a similar provision, scrapping the postponement application process, tenants could potentially have an additional ten months of security

214. See supra Part III.B.

215. HC RESEARCH, supra note 88 , at $12-13$.

216. See Crisis ReSPONSE, supra note 187, at 4; Shelter RESPONSE, supra note 191, at 8.

217. Id.

218. 155 CONG. REC. S8978 (2009).

219. See SHELTER RESPONSE, supra note 191 , at 9.

220. Id.

221. Protecting Tenants at Foreclosure Act of $2009 \S 702$ (a)(2), Pub. L. 111-22, Div. A., May 20, 2009, 123 Stat. 1632. 
of tenure. ${ }^{222}$ Statistics clearly show that society's most vulnerable populations (the poor, the elderly, etc.) are more likely to end up homeless in short-notice eviction situations. ${ }^{223}$ This additional security of tenure would make significant progress toward the goal of reducing the harms of involuntary displacement. As an added bonus, British courts would not be entangled in the postponement application process and judicial costs and caseloads would be reduced.

The MRPTA is a step in the direction of justice, and represents progress toward mitigation of the individual and societal harms that flow from involuntary displacement. But a token reprieve period (as opposed to a full-scale lease continuation provision), and the improvident placement of appeal burdens on tenants, reduce the effectiveness of the statute and hinder it from achieving its full potential to protect British families.

\section{CONCLUSION}

Government action is rarely a panacea for the troubles of society. However-in instances of landlord mortgage default - innocent tenants, and society in general, ${ }^{224}$ are at the mercy of both the disease and the cure. In an area of law where the impacts of involuntary displacement are significant, where the common law is silent, and where the market has failed to appropriately respond, our elected leaders should continue to move swiftly toward enactment and refinement of appropriate public remedies. In the quest to eliminate or mitigate the individual and societal harms of involuntary displacement, one thing is certain: statutory tenant protections must become permanent, comprehensive fixtures of United States and United Kingdom law.

222. If the lease continuation provision recognized leases with up to twelve months remaining and a new, non-fraudulent lease had been signed just prior to the initiation of the repossession action, the tenant may be entitled to the entire 12 month possessory period, versus a mere two-month reprieve under the current reprieve application provision of the MRPTA.

223. See Roisman, supra note 17 , at 823 ; Pelletiere, supra note 41 , at 8.

224. For example, evictions in multi-family units have caused the proliferation of vacant properties in neighborhoods, dramatic drops in property values that affect neighbors and their ability to refinance their own distressed properties, and the endangerment of residents as these properties become targets for "squatters, vandals and thieves." Nicholas Hartigan, No One Leaves: Community Mobilization as a Response to the Foreclosure Crisis in Massachusetts, 45 HARV. C.R.-C.L. L. REV. 181, 188 (2010). 
